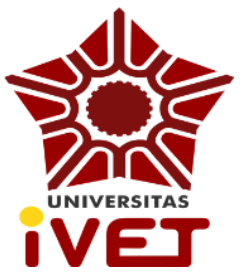

JIPVA (JURNAL PENDIDIKAN IPA VETERAN)

Volume 3 - Nomor 2, 2019

Available at http://e-journal.ivet.ac.id/index.php/jipva

ISSN : 2598-5876 (print), 2598-0904 (online)

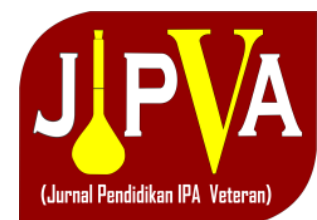

\title{
Model brain based learning untuk meningkatkan keterampilan berpikir kreatif siswa pada materi hukum Newton
}

\author{
Ulfah Khoeriyah*, Ai Nurlaela, Devi Solehat \\ Pendidikan Fisika, Fakultas Imu Tarbiyah dan Keguruan, UIN Syarif Hidayatullah Jakarta, \\ Indonesia \\ *Coressponding author email: ulfah.khoeriyah13@mhs.uinjkt.ac.id
}

\section{Artikel info \\ Received : 20 October 2019 \\ Revised : 15 November 2019 \\ Accepted : 21 November 2019}

\section{Kata kunci:}

Brain based learning

Keterampilan berpikir kreatif

Respon siswa

Hukum Newton

\begin{abstract}
ABSTRAK
Keterampilan berpikir kreatif dalam pembelajaran fisika penting untuk ditingkatkan terkait dengan pengembangan ide-ide dan produktivitas siswa di abad 21. Tujuan dari penelitian ini adalah untuk membuktikan pengaruh penerapan model brain based learning terhadap keterampilan berpikir kreatif dan respon siswa pada materi hukum Newton. Penelitian ini dilakukan pada bulan April sampai Mei 2018 di Madrasah Aliyah Negeri 04 Kabupaten Bogor. Metode penelitian yang digunakan adalah quasi experiment dengan desain nonequivalent control group design. Total sampel dalam penelitian ini terdiri 68 siswa yang terbagi menjadi dua kelas yaitu kelas X MIPA 1 sebagai kelas eksperimen dan X MIPA 2 sebagai kelas kontrol yang diambil secara purposive sampling. Hasil pengujian hipotesis menggunakan uji MannWhitney pada $\alpha=0,05$ menunjukkan adanya signifikansi pengaruh. Respon siswa secara keseluruhan berada pada kategori sangat baik dengan rata-rata nilai persentase sebesar $81 \%$. Dengan demikian, pembelajaran fisika menggunakan model BBL berpengaruh terhadap keterampilan berpikir kreatif siswa.
\end{abstract}

\begin{abstract}
Brain-based learning models to improve students' creative thinking skills on Newton's law topics. Creative thinking skills in learning physics are important to improve related to the development of ideas and students' productivity in the 21 st century. The purpose of this study is to prove the effectiveness of the application of brain-based learning models to creative thinking skills and student responses to Newton's law topics. This research was conducted in April to May 2018 in Madrasah Aliyah Negeri 04 Bogor Regency. The research method used was quasi-experiment with nonequivalent control group design. The total of samples in this study consisted of 68 students who were divided into two classes, namely class $X$ MIPA 1 as an experimental class and X MIPA 2 as a control class taken by purposive sampling. The results of hypothesis testing using the MannWhitney test at $\alpha=0.05$ indicate the significance of the effect. Overall student response was in a very good category with an average percentage score of $81 \%$. Thus, physics learning using the BBL model influences students' creative thinking skills.
\end{abstract}

Keywords:

Brain based learning

Creative thinking skill

Student response

Newton's Law

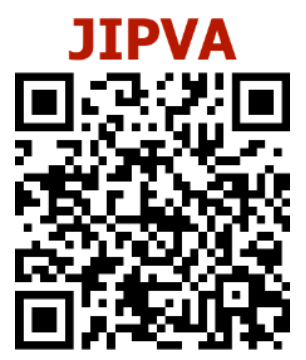

https://doi.org/10.31331/jipva.v3i2.872

How to Cite: Khoeriyah, U., \& Nurlaela, A. (2019). Model brain based learning untuk meningkatkan keterampilan berpikir kreatif siswa pada materi hukum Newton. JIPVA (Jurnal Pendidikan IPA Veteran), 3(1), 179-191. doi: https://doi.org/10.31331/jipva.v3i2.872

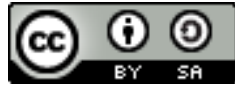

Copyright (C) 2019, Khoeriyah et al. 


\section{PENDAHULUAN}

Perkembangan ilmu pengetahuan abad 21 menuntut siswa menjadi Sumber Daya Manusia (SDM) berkualitas dan mampu berkompetisi. Salah satu hal yang penting untuk dikembangkan yaitu keterampilan berpikir kreatif. Keterampilan berpikir kreatif merupakan cara berpikir yang original, reflektif dan menghasilkan suatu produk yang kompleks (Tendrita, Mahanal, \& Zubaidah, 2016). Keterampilan berpikir kreatif merupakan bagian dari proses pembelajaran untuk membantu siswa menjadi pembelajar sukses dan individu yang percaya diri sehingga penting dikembangkan pada berbagai mata pelajaran. Namun demikian, berpikir kreatif jarang ditekankan pada pembelajaran fisika.

Umumnya orang beranggapan bahwa kreativitas dan fisika tidak ada kaitannya satu sama lain. Para fisikawan sangat tidak setuju dengan pandangan tersebut. Mereka berpendapat bahwa kemampuan fleksibilitas yang merupakan salah satu indikator berpikir kreatif adalah kemampuan yang paling penting bagi seseorang (Kuspriyanto \& Siagian, 2013).

Berdasarkan hasil wawancara dengan guru fisika di salah satu Madrasah Aliyah Negeri (MAN) Kabupaten Bogor menunjukan bahwa kemampuan berpikir kreatif siswa belum pernah diukur secara khusus. Aktivitas pembelajaran yang terjadi hanya satu arah dan terbatas pada menghafal, mendengarkan, mencatat dan terpaku pada soal. Selain itu, evaluasi yang diberikan oleh guru cenderung menggunakan tes konvergen sehingga jawaban siswa tidak bervariasi karena terfokus pada satu jawaban dan tidak dapat memberikan jawaban dengan caranya sendiri. Hal tersebut tentu tidak sesuai dengan indikator berpikir kreatif, khususnya pada berpikir lancar. Nugraheni (2018) menambahkan bahwa rendahnya keterampilan tersebut dikarenakan guru masih belum benar-benar memahami makna dari berpikir kreatif.

Padahal keterampilan berpikir kreatif amat bermakna bagi pengembangan potensi anak secara utuh (Munandar, 2012). Senada dengan Abdurrozak, Jayadinata, \& Isrok'atun (2016), kebanyakan sekolah tidak mendorong para murid untuk memperluas pemikiran mereka dengan menciptakan ide baru dan memikirkan ulang kesimpulan yang sudah ada. Permasalahan tersebut menunjukan bahwa keterampilan berpikir kreatif sangat diperlukan dalam dunia pendidikan untuk menunjang nalar dan analisis siswa sehingga siswa dapat menuangkan apa yang ada pada pemikirannya secara menyeluruh.

Keterampilan berpikir dipengaruhi oleh otak. Otak merupakan pusat dari semua aktivitas termasuk berpikir (Wisudawati \& Anggaryani, 2014). Setiap manusia memiliki susunan otak yang berbeda sesuai dengan tingkat interaksi manusia dengan lingkungannya pada saat otak mengalami perkembangan yang signifikan sehingga seseorang akan memiliki cara kerja otak yang berbeda dengan orang lain (Pandu, 2016). Gambaran yang lebih besar adalah bahwa otak kita terlibat dengan semua yang kita lakukan di sekolah (Jensen, 2011).

Alternatif model pembelajaran yang dapat menciptakan kondisi belajar menyenangkan, kreatif dan aktif melibatkan siswa serta berorientasi pada upaya pemberdayaan potensi otak yaitu brain based learning (BBL) (Tafti \& Kadkhodaie, 2016). Jensen (2011) menyatakan bahwa BBL merupakan pembelajaran yang diselenggarakan dengan cara mendesain otak untuk belajar secara alamiah. Siswa diajarkan untuk mengoptimalkan penggunaan otak kanan dan kiri (Rosita \& Nur, 2016). BBL dirancang berdasarkan struktur dan fungsi setiap bagian dalam otak sehingga dapat melaksanakan kegiatan belajar, asimilasi, berpikir dan mengingat (Uzezi \& Jonah, 2017). 
Berbeda dengan metode pembelajaran tradisional, pembelajaran berbasis otak menekankan pembelajaran yang bermakna bukan hanya menghafal (Tafti \& Kadkhodaie, 2016). Model pembelajaran ini melibatkan penerapan prinsip-prinsip yang dirancang cermat dengan pertimbangan dampak sebelum, selama, dan setelah pembelajaran (Akyurek \& Afacan, 2013). Namun, di sisi lain BBL memberikan kesempatan secara bebas kepada siswa untuk mengembangkan potensi secara alamiah berdasarkan cara kerja otak mereka (Sukoco \& Mahmudi, 2016).

BBL memiliki tujuh tahapan yaitu pra-pemaparan, persiapan, inisiasi dan akuisisi, elaborasi, inkubasi dan pengkodean memori, verifikasi dan pengecekapan kepercayaan, serta selebrasi dan integrasi (Jensen, 2011). Kelebihan dari BBL adalah kelas yang rileks, pembelajaran yang konstruktivistik, menekankan aspek kerjasama antar siswa, adanya cukup waktu bagi siswa untuk merefleksikan materi yang telah diterimanya, pembelajaran yang bermakna dan kontekstual. Selain itu model pembelajaran ini dapat menciptakan lingkungan belajar yang menantang kemampuan berpikir siswa (Saparina, Santosa, \& Maridi, 2013).

Penelitian terdahulu membuktikan bahwa BBL efektif untuk meningkatkan kreativitas baik pada anak usia dini (Kusumawardani, 2013), remaja dan dewasa (Rosita \& Nur, 2016). Namun, belum banyak penelitian yang mengungkap efektivitas model ini dalam pembelajaran Fisika khususnya pada materi Hukum Newton. Model BBL ini diharapkan menjadi solusi dari permasalah yang terjadi dalam pembelajaran fisika, khususnya pada materi hukum Newton yang berdasarkan kompetensi dasarnya memerlukan cara berpikir kreatif untuk menyelesaikan setiap permasalahannya. Siswa diberi pengalaman langsung dalam pembelajaran fisika berdasarkan model BBL sehingga siswa dapat terlibat langsung dalam menemukan berbagai fakta, membangun kreativitas, serta diharapkan dapat meningkatkan keterampilan berpikir kreatif siswa. Oleh karena itu, tujuan penelitian ini yaitu untuk membuktikan pengaruh penerapan BBL terhadap keterampilan berpikir kreatif dan respon siswa pada materi hukum Newton.

\section{METODE}

\section{Jenis Penelitian}

Penelitian ini merupakan ekperimen semu (quasi experiment) dengan desain penelitian nonequivalent control group design yang bertujuan untuk mengetahui keterampilan beripikir kreatif siswa sebelum dan sesudah pembelajaran dengan penerapan model BBL. Dalam desain ini kelompok kontrol maupun kelompok eksperimen tidak dipilih secara random (Sugiyono, 2011). Variabel bebas (independen) berupa model BBL dan variabel terikat (dependen) adalah keterampilan berpikir kreatif.

\section{Waktu dan Tempat Penelitian}

Penelitian ini dilaksanakan di MAN 04 Kabupaten Bogor yang berlokasi di Jalan Stasiun Cigombong Kampung Cijambu Desa Cisalada, Kabupaten Bogor. Penelitian ini berlangsung pada semester genap tahun ajaran 2018/2019 dengan pengambilan data dilakukan selama lima minggu dari 16 April sampai 19 Mei 2018.

\section{Populasi dan Sampel}

Populasi dalam penelitian ini adalah seluruh siswa kelas X MAN 04 Kabupaten Bogor yang berjumlah 105 siswa tahun ajaran 2018/2019. Sampel dalam penelitian ini adalah kelas X 
MIPA 1 dan MIPA 2 yang berjumlah 68 siswa. Sampel ditentukan dengan menggunakan teknik purposive sampling. Pertimbangan dalam pemilihan sampel ini yaitu kelas yang memiliki tingkat kemampuan yang realatif sama. Hasil pemilihan sampel, kelas X MIPA 1 sebagai kelas eksperimen sedangkan X MIPA 2 sebagai kelas kontrol.

\section{Prosedur Penelitian}

Prosedur penelitian ini dibagi menjadi tiga tahap yaitu tahap awal, tahap pelaksanaan dan tahap akhir.

\section{Tahap awal}

Tahap awal merupakan tahap persiapan untuk penelitian. Tahap ini meliputi studi pendahuluan berupa wawancara guru; menganalisis beberapa referensi; merumuskan masalah; mengkaji teori pembelajaran; pengambilan sampel; penyusunan RPP; serta pembuatan instrumen tes dan instrumen nontes berupa angket respon siswa terhadap model $B B L$ yang diterapkan selama penelitian. Kemudian, peneliti membuat surat izin validasi untuk menguji kelayakan intstrumen dan melakukan validasi intsrumen oleh beberapa ahli dan siswa. Instrumen yang telah diuji kelayakannnya akan dianalisis untuk digunakan sebagai pretest dan posttest pengukuran variabel terikat pada penelitian ini.

\section{Tahap Pelaksanaan}

Tahap pelaksanaan merupakan tahap pengambilan data. Tahap ini dimulai dengan pemberian pretest pada kelas kontrol dan eksperimen. Tahap selanjutnya yaitu memberi perlakuan berupa model $B B L$ pada kelas eksperimen dan model pembelajaran konvensional yang telah diterapkan di MAN 04 Kabupaten Bogor dengan konsep yang telah ditentukan. Setelah pemberian perlakuan selesai, tahap selanjutnya yaitu pemberian posttest untuk mengetahui adanya pengaruh terhadap keterampilan berpikir kreatif siswa pada materi hukum Newton dan memberikan angket untuk mengetahui respon siswa terhadap model $B B L$ yang telah diterapkan.

\section{Tahap Akhir}

Tahap akhir adalah tahap analisis dan pelaporan. Pada tahap akhir, peneliti akan mengolah dan menganalisis data yang diperoleh selama tahap pelaksanaan. Kemudia, peneliti akan menguji hipotesis penelitian hingga penarikan kesimpulan. Prosedur yang digunakan dalam penelitian dapat dilihat pada Gambar 1.

\section{Data, Instrumen dan Teknik Pengumpulan Data}

Data yang dikumpulkan dalam penelitian ini yaitu mengenai keterampilan berpikir kreatif siswa pada materi Hukum Newton. Indikator keterampilan berpikir kreatif yang digunakan dalam penelitian ini mengacu pada pendapat Torrance (1965) dengan mengambil 4 indikator yaitu fluency, flexibility, originality dan elaboration. Instrumen dalam penelitian ini adalah hasil tes belajar dan angket. Tes uji coba pada instrumen penelitian dilakukan menggunakan Anatest V4 untuk mengetahui validitas, reliabilitas, daya beda, dan taraf kesukaran. Instrumen juga divalidasi secara kostruksi oleh ahli.

Teknik pengumpulan data yang digunakan dalam penelitian ini dibagi menjadi tiga tahap. Pertama, sebelum pembelajaran observasi dilakukan untuk mengetahui informasi mengenai proses pembelajaran yang biasa diterapkan. Kedua, ketika pembelajaran berupa tes keterampilan berpikir kreatif siswa yang diberikan pada saat pretest dan postest. Ketiga, setelah pembelajaran berupa nontes dengan metode angket yang diberikan kepada kelas eksperimen untuk mengetahui respon siswa terhadap pembelajaran dengan menggunakan model BBL. 


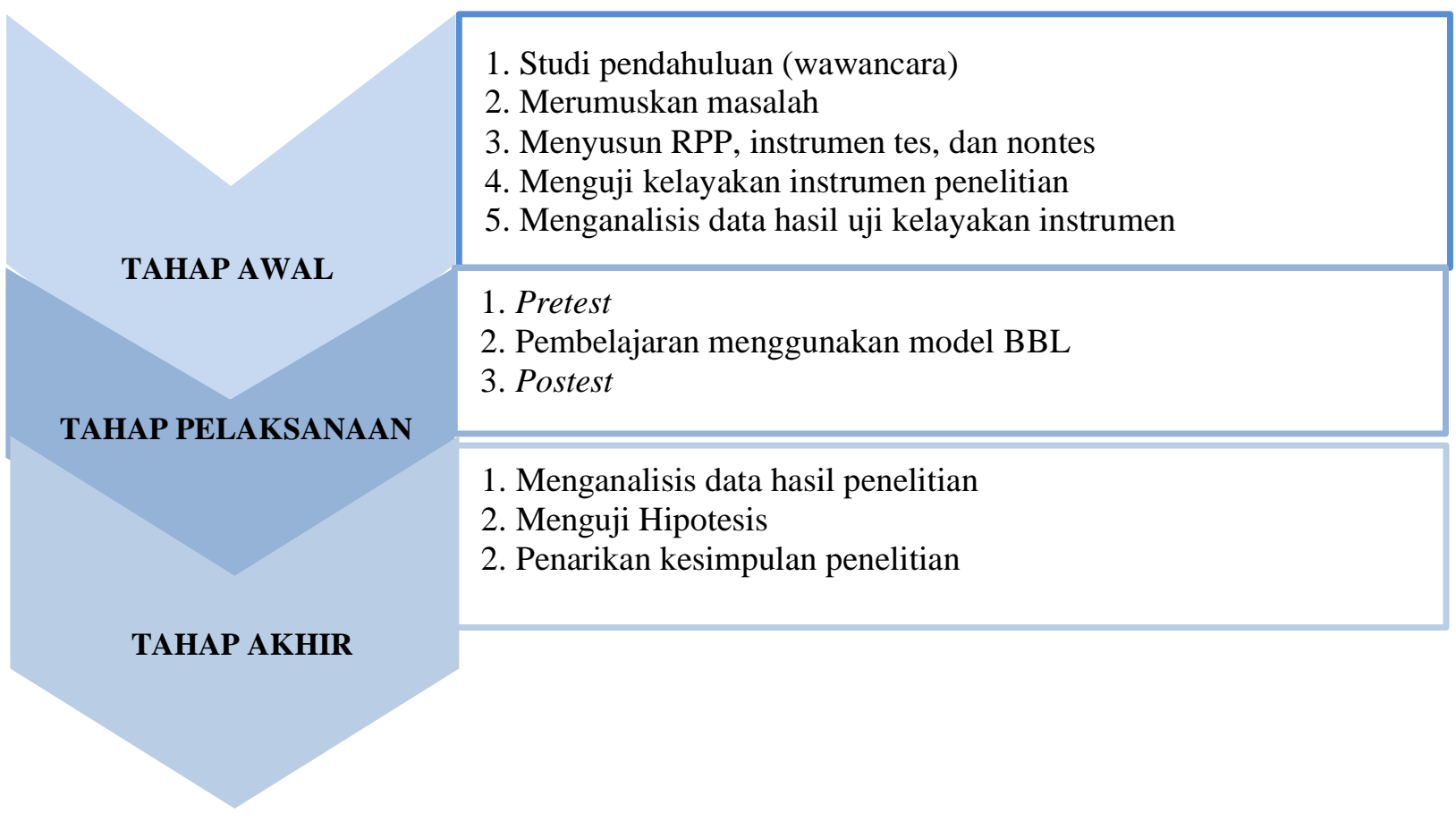

Gambar 1. Prosedur Penelitian

\section{Teknik Analisis Data}

Analisis data pada penelitian ini menggunakan bantuan software SPSS 22 dalam menguji normalitas, homogenitas, dan hipotesis. Uji normalitas dilakukan dengan uji Shapiro-Wilk. Uji Shapiro-Wilk digunakan untuk data kurang dari 50 (Haryadi \& Julianti, 2011) sedangkan uji homogenitas dilakukan dengan menggunakan uji Levene's.

Tiga analisis utama dalam penelitian ini meliputi analisis (1) keterampilan berpikir kreatif berdasarkan pretest dan posttest; (2) peningkatan keterampilan berpikir kreatif berdasarkan indikator kreativitas; dan (3) respon siswa terhadap model BBL. Analisis yang pertama menggunakan perhitungan dengan statistika deskriptif untuk menjabarkan keterampilan berpikir kreatif berdasarkan hasil pretest dna posttest. Analisis kedua digunakan untuk menguji hipotesis. Uji normalized gain digunakan untuk mengetahui peningkatan keterampilan berpikir kreatif siswa pada masing-masing indikator dengan menggunakan rumus dari Hake (1998). Normalized gain atau yang biasa disimbolkan dengan $g$ dihitung melalui skor pretest dan posttest. Selanjutnya, uji hipotesis dalam penelitian ini menggunakan uji Mann-Whitney karena data berdistribusi tidak normal (Kadir, 2015). Analisis ketiga yaitu respon siswa yang dihitung dengan penggunakan teknik persentase (statistika deskriptif).

\section{HASIL DAN PEMBAHASAN}

Guru dituntut untuk kreatif dalam melaksanakan pembelajaran di kelas (Nugraheni, 2018). Pembelajaran yang kreatif dapat mengantarkan siswa menjadi yang kreatif. Berpikir kreatif merupakan salah satu tujuan pembelajaran di abad 21 (Zubaidah, Fuad, Mahanal, \& Suarsini, 2017).Orang yang kreatif memiliki kemampuan yang baik dalam pemecahan masalah baik dalam pembelajaran maupun kehidupan nyata yang dibutuhkan dalam dunia kerja (Im, Hokanson, \& 
Johnson, 2015). Salah satu cara yang dapat dilakukan oleh guru untuk meningkatkan keterampilan berpikir kreatif siswa yaitu dengan menerapkan BBL dalam materi hukum Newton.

Hasil penerapan model BBL dalam penelitian ini dideskripsikan berdasarkan 3 analisis meliputi keterampilan berpikir kreatif berdasarkan pretest-posttest, peningkatan keterampilan berpikir kreatif berdasarkan tiap indikator dan respon siswa terhadap model BBL.

\section{Keterampilan berpikir kreatif berdasarkan pretest-posttest}

Analisis pertama yaitu keterampilan berpikir kreatif berdasarkan pretest-posttest. Rekapitulasi hasil pretest dan postest disajikan dalam Tabel 1.

Tabel 1. Rekapitulasi Data hasil pretest dan posttest

\begin{tabular}{lcccc}
\hline \multirow{2}{*}{$\begin{array}{c}\text { Pemusatan dan } \\
\text { Penyebaran Data }\end{array}$} & \multicolumn{2}{c}{ Kelas Kontrol } & \multicolumn{2}{c}{ Kelas Eksperimen } \\
\cline { 2 - 5 } & Pretest & Posttest & Pretest & Posttest \\
\hline Skor Terendah & 33 & 40 & 28 & 45 \\
Skor Tertinggi & 62 & 81 & 52 & 86 \\
Mean & 46,06 & 57,74 & 36,84 & 69,91 \\
Median & 44 & 57 & 37 & 74 \\
Modus & 40 & 50 & 31 & 76 \\
Standar Deviasi & 8,630 & 11,304 & 6,279 & 11,728 \\
\hline
\end{tabular}

Berdasarakan Tabel 1, diperoleh informasi bahwa keterampilan awal berpikir kreatif siswa kelas kontrol dan kelas eksperimen masih relatif rendah. Beberapa faktor yang menyebabkan rendahnya keterampilan berpikir kreatif siswa yaitu pembelajaran yang terjadi hanya satu arah. Selain itu, evaluasi yang diberikan oleh guru cenderung menggunakan tes konvergen sehingga siswa hanya fokus pada satu jawaban benar dan tidak dapat memberikan jawaban yang berbeda atau dengan caraya sendiri. Akibatnya, proses pembelajaran menjadi pasif. Beberapa contoh yang terjadi pada saat proses pembelajaran yaitu saat guru memberikan kesempatan bertanya, siswa sebagian besar diam, saat diberikan tugas dalam kelompok, masih terdapat beberapa siswa yang tidak ikut serta dalam diskusi kelompok dan ketika presentasi kelompok tidak ada perhatian, dan pendapat dari kelompok lain. Kendala-kendala tersebut menunjukan kurang dilatihnya keterampilan berpikir kreatif siswa yang mengakibatkan rendahnya keterampilan awal berpikir kreatif. Gambaran nilai rata-rata pretest dan posttest kelas eksperimen dan kelas kontrol dapat dilihat pada Gambar 2.

Keterampilan berpikir kreatif siswa meningkat setelah diberi perlakuan yang berbeda pada masing-masing kelas. Peningkatan tersebut dapat dilihat dari rata-rata nilai posttest yang diperoleh. Berdasarkan data tersebut dapat disimpulkan bahwa keterampilan berpikir kreatif kelas eksperimen yang menggunakan model BBL lebih unggul dibandingkan dengan kelas kontrol. Hal ini sejalan dengan penelitian sebelumnya yang dilakukan oleh Gözüyeşill \& Dikici (2014) yang menyatakan bahwa BBL membuat prestasi akademik siswa menjadi lebih tinggi dibandingkan dengan metode pengajaran tradisional. 


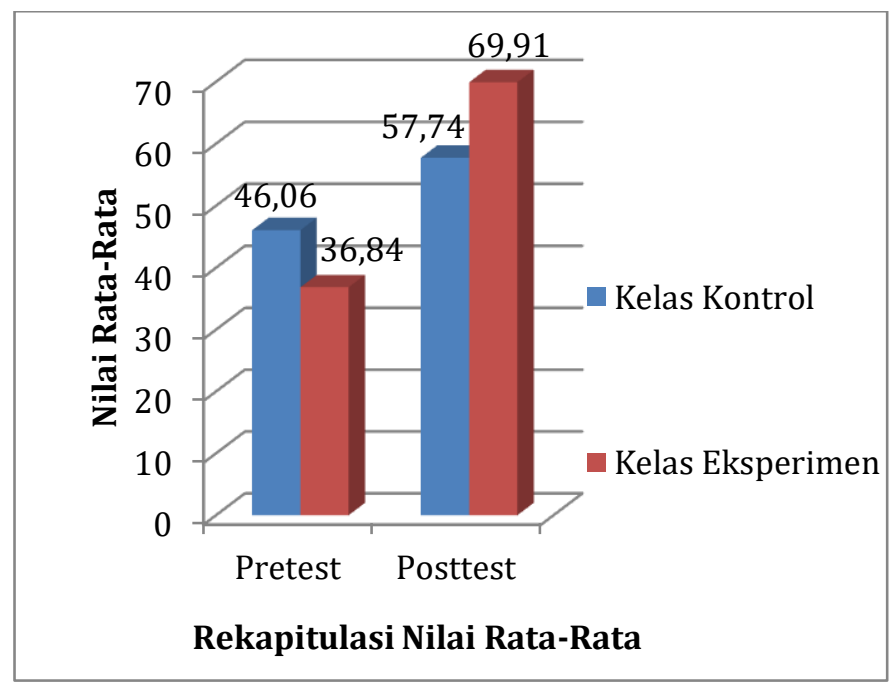

Gambar 2. Diagram Batang Rekapitulasi Nilai Rata-Rata Pretest dan Posttest Kelas Kontrol dan Kelas Eksperimen.

\section{Peningkatan keterampilan berpikir kreatif siswa}

Analisis kedua adalah peningkatan keterampilan berpikir kreatif berdasarkan hasil normalized gain $(g)$ tiap indikator. Indikator keterampilan berpikir kreatif menurut Torrance (1965) dibagi menjadi empat yaitu fluency, flexibility, originality dan elaboration. Hasil normalized gain indikator kreatif pada masing-masing kelas dapat dilihat pada Tabel 2.

Tabel 2. Hasil normalized gain Berdasarkan Indikator Kreatif

\begin{tabular}{lccccc}
\multicolumn{2}{c}{ Indikator Keterampilan Berpikir } & \multicolumn{2}{c}{ Kelas Kontrol } & \multicolumn{2}{c}{ Kelas Eksperimen } \\
\cline { 2 - 5 } & Kreatif & $\boldsymbol{g}$ & Kategori & $\boldsymbol{g}$ & Kategori \\
\hline Fluency & 0,15 & Rendah & 0,55 & Sedang \\
Flexibility & 0,11 & Rendah & 0,57 & Sedang \\
Originality & 0,18 & Rendah & 0,47 & Sedang \\
Elaboration & 0,34 & Sedang & 0,51 & Sedang \\
\hline
\end{tabular}

Berdasarkan data yang diperoleh, setiap indikator berpikir kreatif mengalami peningkatan. Pada keterampilan berpikir fluency (lancar), kelas eksperimen lebih unggul dibandingkan dengan kelas kontrol. Berdasarkan observasi di kelas eksperimen, siswa yang diberi perlakuan pembelajaran menggunakan model BBL cenderung lebih aktif, tidak malu untuk berpendapat, lebih baik ketika mengajukan pertanyaan, gagasan ataupun jawaban. Hal tersebut dikarenakan pembelajaran menggunakan model BBL mengajak siswa untuk terlibat langsung dalam proses pembelajaran sehingga siswa lebih percaya diri dalam mengungkapkan gagasannya. Sejalan dengan penelitian Kuspriyanto \& Siagian (2013) yang menyebutkan bahwa siswa yang tergolong memiliki kemampuan berpikir kreatif tinggi cenderung lebih konsentrasi, lebih termotivasi dan antusias mengikuti pembelajaran.

Model BBL juga dapat meningkatkan keterampilan berpikir kreatif pada indikator berpikir flexibility (luwes). Proses pembelajaran menggunakan BBL pada setiap pertemuan melibatkan siswa untuk berdiskusi secara kolaboratif sehingga siswa terbiasa meninjau masalah dari berbagai sudut pandang yang berbeda dan membuat pemikirannya menjadi luas. Sejalan dengan pernyataan Saparina, Santosa, \& Maridi, (2013) dalam penelitiannya yang menyebutkan bahwa 
adanya diskusi kelompok mengajak siswa membangun konsep bersama secara kooperatif serta dapat melatih kemampuan berkomunikasi untuk menanggapi persoalan di sekitar siswa. Hal ini juga sesuai dengan hasil penelitian yang dilakukan oleh Utomo, Wahyuni, \& Hariyadi (2104) yang menyatakan bahwa pengelompokkan dalam belajar dapat memfasilitasi siswa untuk berkolaborasi, saling tukar pikiran, saling mengajari serta dapat menyelesaikan masalah dengan banyak cara karena memungkinkan timbulnya berbagai pemikiran yang berbeda. Selain itu, pada proses pembelajaran siswa dibiasakan dengan pertanyaan-pertanyaan yang dapat menghasilkan variasi jawaban dalam memecahkan permasalahan. Hal ini sejalan dengan hasil penelitian Saefudin (2012) yang menyatakan bahwa siswa akan lebih mudah memecahkan masalah jika siswa terbiasa menyelesaikannya dengan berbagai penyelesaian.

Pada indikator berpikir kreatif selanjutnya yaitu berpikir originality (asli) kelas eksperimen masih lebih unggul dibandingkan dengan kelas kontrol. Unggulnya kelas eksperimen disebabkan karena pada model BBL terdapat tahap inisiasi dan akuisisi yang dapat melatih keterampilan berpikir original siswa. Pada tahap ini siswa dilibatkan secara aktif dalam percobaan sederhana secara berkelompok untuk menemukan pengetahuannya sendiri, sehingga pembelajaran menjadi bermakna.

Tahap BBL yang dapat melatih keterampilan berpikir kreatif selanjutnya yaitu elaborasi. Pada tahap ini siswa diberikan kesempatan untuk menyortir, menyelidiki, menganalisis, menguji dan memperdalam pembelajaran secara mandiri (Saparina et al., 2013). Selain itu, siswa juga terbiasa untuk mempersentasikan hasil percobaannya. Melalui proses ini siswa belajar berbagi pengetahuan dan mengambil kesimpulan berdasarkan pemikirannya sehingga siswa dapat menciptkan cara-cara baru dalam memecahkan permasalahan. Hal ini sejalan dengan penelitian Utomo et al., (2104) yang menyebutkan bahwa terbentuknya ide baru dan perkembangan intelektual siswa dapat dipacu melalui interaksi sosial dengan teman lain.

Indikator berpikir kreatif yang terakhir yaitu berpikir memerinci (elaboration). Pada indikator ini siswa diminta untuk memperinci detail-detail suatu obyek, gagasan, atau situasi sehingga lebih menarik (Munandar, 2012). Hasil normalized gain kelas eksperimen dan kelas kontrol berada pada kategori sedang. Namun, nilai kelas eksperimen masih lebih tinggi dibandingkan dengan kelas kontrol. Hal ini disebabkan karena pada kelas eksperimen siswa dilatih dengan pembelajaran terurut dengan tujuh tahapan yang terdiri dari pra-pemaparan, persiapan, inisiasi dan akuisisi, elaborasi, verifikasi dan pengecekan kepercayaan, serta selebrasi dan integrasi yang berbasis cara kerja otak dan dapat membuat setiap detail dalam proses pembelajaran tersampaikan dengan terperici.

Berdasarkan hasil analisis data diperoleh informasi bahwa indikator keterampilan berpikir kreatif yang paling tinggi peningkatannya dibandingkan indikator kreatif lainnya yaitu indikator berpikir terperinci (elaboration). Penyebab unggulnya indikator memerinci yaitu siswa dilatih dalam mengerjakan soal secara terperinci. Hal ini sesuai dengan hasil penelitian (Djupanda, Kendek, \& Darmadi (2015) yang menyebutkan bahwa aspek elaborasi memilki skor yang lebih baik dibandingkan aspek berpikir kreatif lainnya. Hal ini dikarenakan aspek elaborasi memiliki kemampuan menjelaskan secara terperinci, runtut dan koheren terhadap prosedur, jawaban atau situasi tertentu.

Pembelajaran berbasis otak menekankan pembelajaran yang bermakna bukan hanya sekedar menghafal. Selain itu, model pembelajaran ini melibatkan penerapan prinsip-prinsip 
yang dirancang cermat dengan pertimbangan dampaknya sebelum, selama, dan setelah pembelajaran (Akyurek \& Afacan, 2013). Wisudawati \& Anggaryani (2014) dalam penelitiannya menyebutkan bahwa keterampilan berpikir dipengaruhi oleh otak. Otak merupakan pusat dari semua aktivitas termasuk berpikir. Oleh karena itu, diperlukan pembelajaran yang meperhatikan dan mengembangkan potensi otak untuk dapat mengembangkan keterampilan berpikir. Hal ini sejalan dengan hasil penelitian sebelumnya yang dilakukan oleh Rosita \& Nur (2016) bahwa BBL dapat mempengaruhi keterampilan berpikir kreatif siswa. Oleh karena itu, setelah diterapkannya model BBL keterampilan berpikir kreatif siswa meningkat.

Berdasarkan uji prasyarat analisis statistik, diperoleh kesimpulan bahwa hasil uji normalitas pada kelas kontrol dan kelas eksperimen tidak terdistribusi normal. Varian kedua kelas baik pretest maupun posttest sama atau homogen. Sehingga, pengujian hipotesis pada kedua data menggunakan uji nonparametrik Mann-Whitney melalui software SPSS. Hasil uji hipotesis pretest dan posttest dapat dilihat pada Tabel 3.

Tabel 3. Hasil Uji Hipotesis Pretest dan Posttest

\begin{tabular}{lll}
\multicolumn{1}{c}{ Mann Whitney } & \multicolumn{1}{c}{ Pretest } & \multicolumn{1}{c}{ Posttest } \\
\hline Asymp. Sig. (2-tailed) & 0,200 & 0,000 \\
$\alpha$ & 0,050 & 0,050 \\
Keputusan & $\mathrm{H}_{1}$ Ditolak & $\mathrm{H}_{1}$ Diterima \\
\hline
\end{tabular}

Hasil uji hipotesis menyatakan bahwa nilai sig. (2-tailed) posttest $<$ taraf signifikansi $(0,05)$ yang artinya $\mathrm{H}_{0}$ ditolak dan $\mathrm{H}_{1}$ diterima. Oleh karena itu, dapat disimpulkan bahwa terdapat perbedaan rata-rata keterampilan berpikir kreatif siswa pada kelas eksperimen dan kelas kontrol. Dengan demikian, model BBL terbukti berpengaruh terhadap keterampilan berpikir kreatif siswa pada materi hukum Newton. Hasil penelitian ini didukung oleh penelitian sebelumnya oleh Saparina et al., (2013) yang mengungkapkan bahwa pembelajaran dengan model BBL berpengaruh terhadap hasil belajar biologi siswa.

Berdasarkan penjelasan di atas, secara umum pembelajaran menggunakan model BBL dapat meningkatkan keterampilan berpikir kreatif siswa. Pembelajaran ini mempertimbangkan bagaimana otak belajar dengan optimal. Ciri khas pada model ini yaitu adanya waktu tak-adakegiatan (downtime) dan waktu tinjauan. Otak belajar tidak semua sekaligus tetapi bertahap, guru dapat menyediakan waktu untuk rileksasi dan peregangan yang dapat disesuaikan dengan desain pembelajaran (Jensen, 2011). Dalam hal ini, guru mengadakan senam otak yang bertujuan untuk menstimulasi otak. Siswa juga diberi kesempatan yang lebih untuk memahami dan mengkonfirmasi permasalahan yang diberikan sehingga mereka dapat menyegarkan lagi pemikirannya. Hal ini sejalan dengan pernyataan Jensen (2011) bahwa pembelajaran mencapai hasil terbaik apabila difokuskan, dipecahkan, kemudian difokuskan kembali. Pembelajaran terfokus secara terus-menerus akan menjadi semakin tidak efisien.

Terkait dengan penerapan BBL untuk meningkatkan keterampilan berpikir kreatif, Zubaidah et al., (2017) menyatakan bahwasannya terdapat perbedaan antara siswa laki-laki dan perempuan. Penelitian lain juga mengungkapkan bahwasannya usia mempengaruhi kematangan dalam berpikir kreatif (Appulembang, 2017). 


\section{Analisis Angket Respon Siswa}

Analisis yang ketiga yaitu repson siswa terhadap model BBL. Hasil angket respon siswa terhadap model BBL dapat dilihat pada Tabel 4.

Tabel 4. Hasil Angket Respon Siswa

\begin{tabular}{clll}
\hline No & \multicolumn{1}{c}{ Indikator Angket } & $\begin{array}{c}\text { Persentase Respon } \\
\text { Siswa }\end{array}$ & \multicolumn{1}{c}{ Interpretasi } \\
\hline 1 & Penggunaan model BBL dalam proses & $83 \%$ & Sangat Baik \\
& pembelajaran. & & Sangat Baik \\
2 & Keterampilan berpikir kreatif siswa & $82 \%$ & Baik \\
3 & Penyampaian konsep materi & $77 \%$ & Sangat Baik \\
\hline
\end{tabular}

Sikap positif siswa terhadap pembelajaran hukum Newton dengan menggunakan model BBL ditunjukkan dengan hasil angket respon siswa secara keseluruhan mendapat tanggapan yang sangat baik dengan persentase rata-rata yaitu $81 \%$. Hal ini sesuai dengan hasil penelitian Akyurek \& Afacan (2013) yang menyatakan bahwa BBL dapat meningkatkan sikap dan motivasi dikelas. Jensen (2011) juga menyatakan bahwa keterampilan berpikir sangat bergantung pada suasana hati (mood) dan keadaan emosional.

BBL yang didesain berdasarkan struktur dan fungsi otak mampu mengoptimalkan kinerja otak itu sendiri. Aktivitas otak bagian posterior kanan yang tinggi berkorelasi positif dengan berpikir kreatif jika dilihat dengan menggunakan magnetic resonance imaging (MRI) (Heilman, 2016). Banyak penelitian yang menunjukkan bahwa BBL dapat juga digunakan untuk meningkatkan berbagai aspek hasil belajar (Uzezi \& Jonah, 2017), motivasi belajar (Akyurek \& Afacan, 2013) dan keterampilan berpikir, diantaranya yaitu berpikir kritis (D. H. Utomo, 2017; Zakkia, Sri, \& Asih, 2019) dan kreatif (Rosita \& Nur, 2016). Implementasi BBL dalam pembelajaran di kelas dapat di kombinasikan dengan berbagai media pembelajaran contohnya Schoology untuk meningkatkan keterampilan berpikir kreatif siswa (Imanuel, Waluya, \& Mariani, 2019)

Penggunaan model BBL dalam penelitian ini memiliki keterbatasan yaitu, pembelajaran menggunakan model BBL membutuhkan waktu yang cukup lama, karena tahapan dari model ini cukup banyak sedangkan waktu yang tersedia terbatas sehingga diperlukan persiapan dan pengaturan kelas yang lebih baik.

\section{SIMPULAN DAN SARAN}

\section{Simpulan}

Berdasarkan hasil penelitian dan pembahasan, dapat disimpulkan bahwa model BBL berpengaruh terhadap keterampilan berpikir kreatif siswa pada materi hukum Newton. Pengaruh tersebut terbukti dari hasil uji hipotesis yang memperoleh nilai sig. (2-tailed) $(0,00)<$ nilai taraf signifikansi $(0,05)$. Peningkatan keterampilan berpikir kreatif kelas eksperimen lebih tinggi dibandingkan kelas kontrol. Hal ini dibuktikan dengan nilai rata-rata normalized gain pada kelas eksperimen yang lebih unggul dibandingkan dengan kelas kontrol. Normalized gain kelas eksperimen berada pada kategori sedang sementara, kelas kontrol berada kategori rendah. Respon siswa terhadap model BBL dalam proses pembelajaran pada materi hukum Newton secara keseluruhan mendapat tanggapan sangat baik. 


\section{Saran}

Berdasarkan penelitian yang telah dilaksanakan, penulis mengajukan beberapa saran, diantaranya yaitu (1) sebelum proses pembelajaran dimulai, hendaknya guru mempersiapkan susunan kelompok dan mengalokasikan waktu pembelajaran dengan matang agar pembelajaran menjadi lebih optimal, karena model BBL ini membutuhkan waktu yang cukup banyak dalam penerapannya; dan (2) hasil penelitian menunjukan bahwa penerapan model BBL dapat meningkatkan keterampilan berpikir kreatif siswa. Hal ini dapat dijadikan alternative dalam pemilihan model pembelajaran yang dapat mengoptimalkan potensi otak.

\section{DAFTAR PUSTAKA}

Abdurrozak, R., Jayadinata, A. K., \& Isrok'atun, I. (2016). Pengaruh model problem based learning terhadap kekampuan berpikir kreatif siswa. Jurnal Pena Ilmiah, 1(1), 2016. https://doi.org/https://doi.org/10.23819/pi.v1i1.3580

Akyurek, E., \& Afacan, O. (2013). Effects of brain-based learning approach on students' motivation and attitudes levels in science class. Mevlana International Journal of Education (MIJE), 3(1), 104-119. Retrieved from https://eric.ed.gov/?id=ED543600

Appulembang, Y. A. (2017). Norma kreativitas menggunakan Torrance test of creativity thinking untuk anak usia 6-12 tahun. Provitae Jurnal Psikologi Pendidikan, 9(1), 41-57.

Djupanda, H., Kendek, Y., \& Darmadi, I. W. (2015). Analisis keterampilan berpikir kreatif siswa SMA dalam memecahkan masalah fisika. Jurnal Pendidikan Fisika Tadulako (JPFT), 3(2), 29-34.

Gözüyeşil, E., \& Dikici, A. (2014). The effect of brain based leraning on academis achievement: A meta-analytical study. Educational Sciences: Theory \& Practice, 14(2), 642-648. https://doi.org/10.12738/estp.2014.2.2103

Hake, R. R. (1998). Interactive-engagement vs traditional methods: A six-thousand-student survey of mechanics test data for introductory physics courses. American Journal of Physics, 66(1), 64-74.

Haryadi, S., \& Julianti, W. (2011). SPSS vs LISREL: sebuah pengantar, aplikasi untuk riset. Jakarta: Salemba Empat.

Heilman, K. M. (2016). Possible brain mechanisms of creativity. Archives of Clinical Neuropsychology, 31(March), 285-296. https://doi.org/10.1093/arclin/acw009

Im, H., Hokanson, B., \& Johnson, K. K. P. (2015). Teaching creative thinking skills: A longitudinal study. Clotihing and Textiles Research Journal, 33(2), 129-142. https://doi.org/10.1177/0887302X15569010

Imanuel, I., Waluya, S. B., \& Mariani, S. (2019). The effectiveness of brain based learning assisted by schoology towards students' creative thinking and self-efficacy. Journal of Primary Education, 10(3), 274-281.

Jensen, E. (2011). Pembelajaran berbasis otak. Jakarta: PT Indeks.

Kadir, K. (2015). Statistik terapan (2nd ed.). Jakarta: PT Rajawali.

Kuspriyanto, B., \& Siagian, S. (2013). Strategi pembelajaran dan kemampuan berpikir kreatif. Jurnal Teknologi Pendidikan, 6(1), 134-148. 
Kusumawardani, R. (2013). Peningkatan kraetivitas melalui pendekatan brain based learning. $\begin{array}{llll}\text { Jurnal Pendidikan Usia } & \text { Dini, } & \text { 143-162. }\end{array}$ https://doi.org/https://doi.org/10.21009/JPUD.091

Munandar, U. (2012). Pengembangan kreativitas pada anak berbakat. Jakarta: PT. Rineka Cipta. Jakarta: PT Rineka Cipta.

Nugraheni, D. (2018). Pengembangan lembar kegiatan siswa (LKS) berbasis inquiry materi pengukuran untuk meningkatkan kreativitas siswa. Natural, 5(2), 98-103. https://doi.org/10.30738/natural.v5i2.3252

Nugraheni, D. (2018). Project based learning in heat and transfer material to increase student's creativity. Jurnal Penelitian Pembelajaran Fisika, 9(2), 73-79. https://doi.org/10.26877/jp2f.v9i2.2798

Pandu, G. (2016). Dongkrak kinerja otak berpikir lebih cepat. Yogyakarta: Diva Press.

Rosita, I., \& Nur, D. (2016). Meningkatkan kemampuan berpikir kreatif matematis dan kemandirian belajar siswa dengan menggunakan model pembelajaran brain based learning. Jurnal Pendidikan, 4(1), 26-41.

Saefudin, A. A. (2012). Pengembangan kemampuan berpikir kreatif dalam pembelajaran matematika dengan pendekatan matematika ralistik indonesia (PMRI). Al-Bidayah, 4(1), 37-48. https://doi.org/https://doi.org/10.14421/al-bidayah.v4i1.10

Saparina, R., Santosa, S., \& Maridi, M. (2013). Pengaruh model brain based learning (BBL) terhadap hasil belajar biologi siswa kelas X SMA Negeri Colomadu tahun pelajaran 2012/2013. Bio-Pedagogi, 2(2), 78-91. Retrieved from http://www.jurnal.fkip.uns.ac.id/index.php/pdg/article/view/5524

Sugiyono, S. (2011). Metode penelitian kuantitatif, kualitatif dan R\&D. Bandung: Alfabeta.

Sukoco, H., \& Mahmudi, A. (2016). Pengaruh pendekatan brain-based learning terhadap kemampuan komunikasi matematis dan self-efficacy siswa SMA. Phytagoras: Jurnal Pendidikan Matematika, 11(1), 11-24. https://doi.org/10.21831/pg.v11i1.9678

Tafti, M. A., \& Kadkhodaie, M. S. (2016). The effects of brain-based training on the learning and retention of life skills in adolescents. International Journal of Behavioural Science, 10(4), 140-144.

Tendrita, M., Mahanal, S., \& Zubaidah, S. (2016). Pemberdayaan keterampilan berpikir kreatif melalui model remap think pair share. In Proceeding Biology Education Conference (Vol. 13, pp. 285-291).

Torrance, E. P. (1965). Scientific views of crativity and factors affecting its growth. Creativity and Learning, 94(3), 663-681.

Utomo, D. H. (2017). Brain based learning: effects model a-car in critical thinking skills. Advances in Social Science, Education and Humanities Research, 79, 339-343.

Utomo, T., Wahyuni, D., \& Hariyadi, S. (2104). Pengaruh model pembelajaran berbasis masalah (problem based learning) terhadap pemahaman konsep dan kemampuan berpikir kratif siswa. Jurnal Edukasi, 1(1), 5-9. https://doi.org/https://doi.org/10.19184/jukasi.v1i1.1025

Uzezi, J. G., \& Jonah, K. J. (2017). Effectiveness of brain-based learning strategy in students' academic achievement, attitude, motivation and knowledge retention in electrochemistry. Journal of Education, Society and Behavioural Science, 21(3), 1-13. https://doi.org/10.9734/JESBS/2017/34266 
Wisudawati, A., \& Anggaryani, M. (2014). Penerapan pembelajaran fisika berdasarkan strategi brain based leraning untuk meningkatkan keterampilan berpikir kritis siswa pada materi elastisitas kelas XI di SMA Negeri 1 Wonoayu Sidoarjo. Jurnal Inovasi Pendidikan Fisika (JIPF), 03(02), 1-5.

Zakkia, A., Sri, T., \& Asih, N. (2019). Kemampuan literasi matematika siswa pada pembelajaran brain based learning. Prisma, Prosiding Seminar Nasional Matematika, 2, 34-39.

Zubaidah, S., Fuad, N. M., Mahanal, S., \& Suarsini, E. (2017). Improving creative thinking skills of students through differentiated science inquiry with mind map. Journal of Tur, 14(4), 7791. https://doi.org/10.12973/tused.10214a

\section{PROFIL SINGKAT}

Ulfah Khoeriyah lahir di Bogor 29 Juni 1995. Ia memperoleh gelar sarjananya di Pendidikan Fisika, Fakultas Imu Tarbiyah dan Keguruan, UIN Syarif Hidayatullah Jakarta. Email : ulfah.khoeriyah13@mhs.uinjkt.ac.id.

Ai Nurlaela lahir di Sukabumi pada 12 November 1979. Ia mendapatkan gelar magisternya pada jurusan Biofisika IPB. Saat ini Ia aktif mengajar di Pendidikan Fisika, Fakultas Imu Tarbiyah dan Keguruan, UIN Syarif Hidayatullah Jakarta. Email : ai.nurlaela@uinjkt.ac.id.

Devi Solehat, lahir di Sumedang, 31 Januari 1987. Ia menamatkan pendidikan masternya di jurusan S2 Pendidikan Fisika. Saat ini Ia merupakan dosen di Pendidikan Fisika, Fakultas Imu Tarbiyah dan Keguruan, UIN Syarif Hidayatullah Jakarta. Email : devi.sholehat@uinjkt.ac.id . 